KAWISTARA

VOLUME 4

No. 3, 22 Desember 2014

Halaman 225-330

\title{
BENTUK ORTOGRAFI ISTILAH SERAPAN BAHASA INGGRIS KE DALAM BAHASA ARAB
}

\author{
Rika Astari \\ Program Studi Bahasa dan Sastra Arab \\ Universitas Ahmad Dahlan Yogyakarta \\ Email: astari.rika@yahoo.co.id \\ Syamsul Hadi \\ Fakultas Ilmu Budaya \\ Universitas Gadjah Mada \\ Soepomo Pudjosudarmo \\ Universitas Sanata Dharma Yogyakarta \\ Suhandano \\ Fakultas Ilmu Budaya \\ Universitas Gadjah Mada
}

\begin{abstract}
This article aimed to analyze the orthographic form of English loan- terms into Arabic fonotaktik. the scope of the consonant grapheme. It is a kind of descriptive qualitative study, which tends to analyze the data inductively. Both distributional method and identity method were used for analyzing the data. The result of this study shows that English loan terms denoted in Arabic consists of a symbol graphemes conditional and unconditional symbol. In general, English loan terms into Arabic in accordance with fonotaktik Arabic, but not in substitution the conditional grapheme. It was found that there are still some Arabic word forming from English which are not appropriate with the Arabic structures and systems because of several reasons: (1) a single grapheme of English loan-terms is adapted to many graphemes; (2) a single grapheme of English loan- terms could symbolize many phonemes; (3) some English terms loan-terms had the phonotactical forms which could not be found in Arabic language, such as words that consist of more than one consonant. The research therefore suggested the consonants changes which determined by Majma 'Lughah
\end{abstract}

Keywords: Orthographic Forms, English Loan-terms, Consonant Graphemes.

\section{ABSTRAK}

Artikel ini bertujuan untuk menganalisis bentuk ortografi dan penyesuaian istilah serapan Inggris ke dalam fonotaktik bahasa Arab, pada lingkup grafem konsonan. Penelitian ini bersifat deskriptif kualitatif, penelitian kualitatif cenderung menganalisis data secara induktif. Metode distribusional (distributional method) dan metode padan (identiry method) digunakan dalam analisis data. Disimpulkan bahwa istilah serapan dari bahasa Inggris dilambangkan ke dalam bahasa Arab terdiri dari lambang grafem yang bersyarat dan lambang grafem yang tidak bersyarat. Secara umum, istilah serapan dari bahasa Inggris ke dalam bahasa 
Arab sesuai dengan fonotaktik Arab, tetapi tidak pada penggantian grafem yang bersyarat. Hal ini disebabkan oleh beberapa hal: pertama adanya satu grafem dari istilah serapan yang disesuaikan dengan banyak grafem; kedua, adanya satu grafem dari istilah serapan yang dapat melambangkan banyak fonem ; ketiga, adanya istilah serapan memiliki fonotaktik yang tidak terdapat dalam bahasa Arab sebelumnya, seperti istilah yang memiliki gugus konsonan. Temuan lainnya, yaitu penambahan lambang grafem konsonan yang telah ditetapkan oleh Majma' Lughah.

Kata Kunci: Bentuk Ortografi, Istilah Serapan Inggris, Grafem Konsonan

\section{PENGANTAR}

Bahasa merupakan salah satu alat komunikasi manusia yang bersifat dinamis dan berkembang, seiring dengan dinamisasi dan perkembangan kehidupan manusia itu sendiri. Faktor yang mempengaruhi kondisi tersebut di antaranya adalah adanya interaksi dan hubungan pengguna bahasa tertentu dengan masyarakat pengguna bahasa yang lain secara intens. Hal ini menimbulkan kontak bahasa yang mengakibatkan terjadinya serapan bahasa dalam penggunaannya di antara masyarakat bahasa tersebut.

Bahasa Arab, pada masa modern kontak antara Barat dan Timur berawal dari Libanon yang mengadakan hubungan dengan dunia Barat sejak awal abad ketujuh belas dan peristiwa penting dalam sejarah Timur Tengah modern adalah Ekspedisi Napoleon ke Mesir pada tahun 1798. Ekspedisi ini mendorong timbulnya Egyptology yang menyebabkan berkembanganya kontakkontak yang berkelanjutan antara Mesir dan Dunia Arab sejak awal abad kesembilan belas (Chejne, 1996: 104). Penyerapan bahasa Inggris menempati urutan terbanyak dibandingkan beberapa bahasa lainnya. Pengaruh dari bahasa Inggris ini banyak terserap di pesisir Teluk Arab dan diperkirakan mencapai jumlah lebih dari 3.000 (tiga ribu) kata (Hadi, 2005: 2). Intensitas interaksi tersebut menimbulkan saling meminjam dalam penggunaannya sehingga terjadilah serapan bahasa.
Serapan bahasa ini menimbulkan beberapa permasalahan yang disebabkan oleh perbedaan-perbedaan serta kekhasan masing-masing bahasa, salah satunya yaitu bentuk ortografi dari bahasa sumber ke bahasa peminjam, yang dalam hal ini adalah antara bahasa Inggris dan bahasa Arab. Jika ditinjau dari sudut kekerabatan bahasa, kedua bahasa ini bukan berasal dari bahasa yang serumpun. Bahasa Inggris termasuk rumpun bahasa Indo-Eropa, sedangkan bahasa Arab termasuk rumpun bahasa Semito-Hamit (Kridalaksana, 2008: xlii). Perbedaan-perbedaan tersebut pada dasarnya menyangkut beberapa hal berikut ini: pertama, bahasa Arab menggunakan huruf Arab sedangkan bahasa Inggris menggunakan huruf latin, bunyi vokal dan diftong dalam bahasa Arab ditulis dengan harakat, dan fonem ganda bahasa Inggris ditulis dengan huruf ganda sedangkan dalam bahasa Arab menggunakan tasydid; kedua, berdasarkan pedoman IPA (International phonetik alfabeth), bahasa Inggris mempunyai 23 bunyi yang tidak terdapat dalam bahasa Arab antara lain: $[\Lambda$ ], [a: ], [æ], [e ],

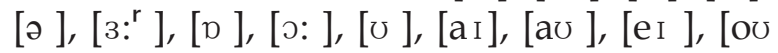

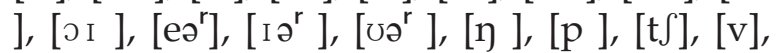
[3]; ketiga, bahasa Arab mempunyai 10 bunyi yang tidak terdapat dalam bahasa Inggris

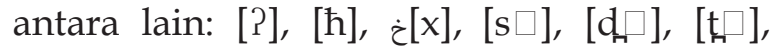

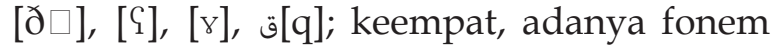
suprasegmental berupa tekanan panjang ( $\mathrm{mad}$ ) pada vokal bahasa Arab.

Berkenaan dengan kata pinjaman, Haugen (1992:286) mengklasifikasikan hasil penyerapan dengan loanwords (kata serapan), loanblends (campuran serapan) atau hybrids (hibrida), dan loanshifts (geseran serapan). Dampak dari fenomena ini berpengaruh pada bahasa lisan maupun tulisan. Sebagaimana dijelaskan Crowley (1992), semula perubahan itu terjadi pada bahasa lisan yang berupa bunyi (sound change), kemudian dari perubahan bahasa lisan ini berakibat pula pada bahasa tulis atau ortografi.

Berdasarkan pemaparan di atas, artikel ini bertujuan untuk menganalisis bentuk ortografi dan penyesuaian istilah serapan 
Inggris ke dalam fonotaktik bahasa Arab, pada lingkup grafem konsonan. Hal ini dimaksudkan untuk mengamati fenomena lambang grafem konsonan dari bahasa Inggris ke dalam bahasa Arab sehingga dapat dibandingkan dengan kaidah pergantian konsonan yang ditetapkan oleh Majma Lugah. Rincian dari pembahasan ini dapat digunakan sebagai pedoman lambang grafem konsonan guna pengembangan dan pemeliharaan bahasa Arab yang sesuai dengan standar kaidah bahasa Arab.

\section{Teori Perubahan Bunyi}

Menurut Sloat (1978: 112-121), istilah perubahan bunyi disebut dengan natural processes (proses alamiah). Natural processes terbagi menjadi dua bagian besar, yaitu assimilatory processes dan nonassimilatory processes. Assimilatory processes adalah proses alamiah pengasimilasian suatu bunyi dengan bunyi lain. Berikut ini adalah bermacammacam tipe asimilasi: (a) nasalization; (b) nasal assimilation; (c) palatalization; (d) assibilation; (e) intervocalic voicing; (f) intervocalic weakening; $(\mathrm{g})$ vowel assimilation; (h) umlaut. Kedua, Nonassimilatory processes: yaitu (a) rhotacism (rotasi); (b) breaking; (c) vowel reduction (reduksi vokal); (d) apocope; (e) syncope; (f) prothesis; (g) epenthesis; (h) metathesis; (i) dissimilation.

Di lain sisi, pola bunyi bahasa Arab (Khasārah, 2008:291) ditentukan oleh: (1) keberagaman huruf dalam suatu kata bahasa Arab; (2) kesesuaian hurufnya, syarat fasihnya kata bahasa Arab dinilai dari hurufhurufnya yang beragam, jarak yang jauh antara makhraj huruf (tempat keluarmya huruf) yang satu dengan yang lainnya dalam suatu kata; (3) keselarasan harakat. Harakat merupakan bagian dari susunan kata bahasa Arab berguna untuk membedakan makna dan suara untuk memudahkan pengucapan dari huruf sukun. Adapun bentuk ketidakselarasan yang dimaksud sebagai berikut: (a) dhammah sebelum waw pada ism. Al-Mulukī berpendapat bahwa ism yang diakhiri dengan waw dan dhammah sebelumnya, tidak terdapat dalam kosakata bahasa Arab kecuali pada fi'l seperti يدعر sehingga kata الرِّو diganti menjadi الرَّبَ (b) dua harakat yang saling berlawanan yaitu kasrah dan dhammah, sehingga tidak terdapat perpindahan dari kasrah ke dhammah karena pengucapannya berat, (c) kasrah sebelum waw sukun dan dhammah sebelum ya sukun, (d) tidak mengumpulkan Empat huruf berharakat semua, jika ada diharakatkan salah satunya, (e) melarang bertemunya dua sukun dalam satu kata, salah satu kekhasan bahasa Arab yaitu tidak mempertemukan dua sukun maka untuk mengatasinya diberikan harakat ghairu läzimah meskipun pada dua kata.

\section{Kaidah Pembentukan Istilah Lembaga Bahasa Arab (Majma' al-Lugah )}

Negara-negara Arab memiliki Majma' al-Lugah yang secara umum bertujuan untuk menjaga pertumbuhan dan perkembangan bahasa Arab sebagai bahasa ilmu dan kajian ilmiah. Sementara itu Majma' al-Lugah al'Arabiyyah di Kairo, menetapkan peranannya (Qanibiy, 2000: 102-103) sebagai berikut: Pertama, menjaga kemurnian bahasa dan membuatnya sesuai kebutuhan dan tuntutan ilmu pengetahuan di masa yang akan datang. Contohnya yaitu mengadakan pembaharuan terhadap kamus-kamus, dari segi metode penyusunan, lafal dan strukturnya; Kedua, menyusun dan membuat kamus sejarah bahasa Arab; Ketiga, meregulasi studi dialek bahasa Arab di Mesir dan negara Arab lainnya; Keempat, melaksanakan kajian dan upaya penjagaan terhadap perkembangan bahasa sesuai dengan ketetapan Menteri Ilmu Pengetahuan.

Majma' Cairo dalam kongresnya yang ke-26 pada tahun 1959 membuat 23 kaidah untuk membuat lambang dan bunyi dari bahasa Yunani dan Latin ke dalam bahasa Arab, kemudian pada kongres ke-30 tahun 1963 dibuat kaidah lambang huruf konsonan dari bahasa Asing. Adapun lambang hurufhuruf konsonannya yaitu: 
Tabel 1

Daftar Lambang Huruf-Huruf Konsonan

\begin{tabular}{|c|c|c|}
\hline النطق العربي الموافق & الحرف اللإتينى & 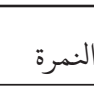 \\
\hline 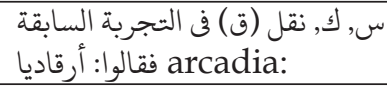 & $\mathrm{C}$ & 1. \\
\hline j, & $\mathrm{D}$ & 2. \\
\hline ف & $F$ & 3. \\
\hline$ج . \dot{\zeta}$ & G & 4. \\
\hline ه, (ونقل (أ) ايضافى التجربة & $\mathrm{H}$ & 5. \\
\hline تش (بالإنكليزية), شبالألمانية, ذٔ, & $\mathrm{CH}$ & 6. \\
\hline \multirow{2}{*}{ ي (بالألمانية), ج (بالفرنسية), خ } & $\mathrm{J}$ & 7. \\
\hline & $\mathrm{P}$ & 8. \\
\hline ف & PH- $\phi$ & 9. \\
\hline s) & $\mathrm{K}$ & 10. \\
\hline ك, كنقل (ق) فى التجربة السابقة & $Q$ & 11. \\
\hline
\end{tabular}

\begin{tabular}{|c|c|c|}
\hline النطق العربي الموافق & الحارف الإغريقيى & 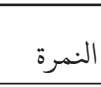 \\
\hline تر تقل (ط) في التجربة السابقة, :فتالوا طيطوسفى & $\mathrm{T}$ & 12. \\
\hline ذ & TH- $\theta$ & 13. \\
\hline \multirow{2}{*}{ س,ش,ص } & S & 14. \\
\hline & $\mathrm{V}$ & 15. \\
\hline, $\mathrm{g}$ & $\mathrm{W}$ & 16. \\
\hline كس, ك, س, كزر, & $X$ & 17. \\
\hline 管 & $\mathrm{Z}$ & 18. \\
\hline & $\Psi$ & 19. \\
\hline
\end{tabular}

\section{Kaidah Fonotaktik Bahasa Arab}

MenurutKridalaksana(2008:65)fonotaktik merupakan urutan fonem yang dimungkinkan dalam suatu bahasa atau pendeskripsian tentang urutan tersebut. Terkait dengan fonotaktik bahasa Arab, Khasārah (2008: 298) mengulasnya sebagai berikut:

Tabel 2

Kaidah Fonotaktik bahasa Arab

\begin{tabular}{|c|c|c|c|c|c|c|c|c|c|}
\hline No & Huruf & \multicolumn{8}{|c|}{$\begin{array}{l}\text { Tidak disatukan dengan huruf-huruf berikut dalam satu kata (baik diletakkan } \\
\text { di awal maupun di akhir kata) }\end{array}$} \\
\hline 1. & $ث$ & سر & ظ & ض & ص & j & $j$ & & \\
\hline 2. & $j$ & س. & ض & ص & ظ & $b$ & j & & \\
\hline 3. & j & س & ظ & ص & j & ث & س & & \\
\hline 4. & ص & ض & س & ظ & $b$ & j & $\dot{j}$ & & \\
\hline 5. & ض & ش & س & ظ & $b$ & ص & j & & \\
\hline 6. & ظ & س & ج & ص & $b$ & j & ض & j & د \\
\hline 7. & $\dot{\tau}$ & $\dot{\varepsilon}$ & $\varepsilon$ & $\tau$ & $\dot{\varepsilon}$ & & & & \\
\hline 8. & $\tau$ & $\dot{\varepsilon}$ & $\dot{\tau}$ & - & - & & & & \\
\hline 9. & T. & $\dot{\varepsilon}$ & b & $b$ & ق & & & & \\
\hline 10. & $\dot{\varepsilon}$ & $\varepsilon$ & $\dot{\tau}$ & $\tau$ & ج & & & & \\
\hline 11. & ث & $j$ & $j$ & ص & ض & ظ & س & & \\
\hline
\end{tabular}

Pada umumnya, kajian terhadap aspek bahasa dalam rangka menemukan pola atau kaidah yang bersifat mengatur di dalam bahasa dilakukan dengan model kualitatif. Untuk itu, kajian artikel ini bersifat deskriptif kualitatif yang menganalisa data secara induktif. Secara rinci, data diperlakukan dalam tiga tahapan, yakni; tahap penyediaan (pengumpulan) data, tahap analisis data dan tahap penyajian hasil analisis data (Sudaryanto, 1986: 57). Metode penyediaan data diawali dengan pengumpulan data berupa istilah serapan sainstek dalam bahasa Arab. Pengumpulan data dilakukan dengan metode simak (Sudaryanto, 1986: 62), dengan teknik catat (Kesuma, 2007: 44) yaitu mencatat data objek penelitian dari ragam tulisan, kemudian dilanjutkan dengan pengklasifikasian data. Untuk menganalisa data digunakan metode deskriptif. Metode deskriptif berpandangan bahwa bahasa adalah fenomena apa adanya tanpa menilai salah dan benar suatu data bahasa, yang sifatnya seperti potret, pemerian apa adanya (Sudaryanto, 1986: 62). Disebabkan luasnya pembahasan, maka ruang lingkup tulisan ini dibatasi pada bidang sainstek dalam kamus-kamus Arab antara lain: 
Al-Mawrid: A Modern English Arabic Dictionary (2009) karya Munīr Ba'albākī, Munawwir Digital Program Version 1.1 Al-Wusțo Digital Publishing (2010), kamus Ațlas English-Arabic (2005).

Adapun jumlah data berupa istilah sains dan teknologi sebanyak 1824 istilah terdiri dari: bidang astronomi (320 istilah), geografi (101), pertanian (46 istilah), biologi (282 istilah ), fisika (224 istilah), kimia (149), kedokteran (258 istilah), matematika (210 istilah), farmasi (101 istilah), dan teknologi sistem informasi dan komunikasi sebanyak (133 istilah). Semua data tersebut tidak diberikan tanda bahwa sebuah kata berasal dari bahasa asing. Kemudian istilah serapan yang berasal dari bahasa Inggris tersebut ditelusuri pelafalannya dalam kamus Merriam Webster dan kamus Atlas English-Arabic (2005). Kedua kamus tersebut merupakan kamus etimologi sehingga kata yang bukan berasal dari bahasa Inggris diberi tanda asal kata asing. Dengan melihat makna asalnya diyakini bahwa datadata tersebut valid dan benar-benar berasal dari bahasa Inggris sehingga dapat dijadikan obyek penelitian. Data-data yang ditemukan dicatat dan ditabulasi dalam komputer. Selain itu data-data tersebut diketik dan diurutkan secara alfabetis untuk membantu mempermudah proses analisis berupa pengurutan, klasifikasi, dan perbandingannya dengan data-data yang lain.

\section{PEMBAHASAN \\ Lambang Grafem yang Bersyarat}

Ortografi istilah Inggris dilambangkan dengan grafem-grafem bahasa Arab sebagai berikut:

\section{Grafem /c/ Dilambangkan dengan Grafem / / /א/, / / /}

Grafem /c/ dapat dilambangkan dengan grafem /ش/, / / / / / ketika istilah tersebut dipinjam ke dalam bahasa Arab. Grafem /c / dengan posisi di awal kata yang melambangkan fonem [k] maka dalam bahasa Arab ditulis dengan grafem / s/, yang melambangkan fonem [s] maka dalam bahasa Arab ditulis dengan grafem / w/. Grafem /c/ di tengah kata bahasa Inggris berbunyi [s], seperti dalam istilah calcimine [kælsimjn], maka الكَلْيمين [al-kalsi:mi:n] dan jika grafem tersebut terletak di akhir istilah dan melambangkan fonem $\left[\mathrm{t}_{\mathrm{f}]}\right]$ seperti dalam istilah caliche $\left[\mathrm{k}_{\varepsilon}\right.$ li $\left.\mathrm{t}_{\mathrm{f}]}\right]$ maka dalam bahasa Arab ditulis dengan grafem / ش/. Sebagaimana tampak pada tabel berikut:

Tabel 3

Grafem / c / Dilambangkan dengan Grafem / / / / / / /.

\begin{tabular}{|c|c|c|c|c|c|c|c|}
\hline No & $\begin{array}{c}\text { Distri } \\
\text { busi }\end{array}$ & $\begin{array}{l}\text { Bahasa } \\
\text { Inggris }\end{array}$ & $\begin{array}{c}\text { Transkipsi } \\
\text { Fonetis }\end{array}$ & $\begin{array}{c}\text { Bahasa } \\
\text { Arab }\end{array}$ & $\begin{array}{l}\text { Transkipsi } \\
\text { Ortografis }\end{array}$ & $\begin{array}{c}\text { Transkipsi } \\
\text { Fonetis }\end{array}$ & $\begin{array}{c}\text { Perubahan } \\
\text { Grafem }\end{array}$ \\
\hline 1. & awal & cable & [kebəl] & لم الكَبْل & [al-kablu] & [al-kablu] & $c \rightarrow s$ \\
\hline 2. & tengah & calcimine & [kælsimIn] & الكَلْسيمين & [al-kalsīmīn] & [al-kalsi:mi:n] & س س \\
\hline 3. & akhir & caliche & {$\left[\mathrm{k} \varepsilon l i \mathrm{t}_{f}\right]$} & الكاليش & [al-kalīsy] & [al-kalaif] & $c \rightarrow A$ \\
\hline
\end{tabular}

Istilah tersebut di atas sudah sesuai dengan kaidah fonotaktik bahasa Arab, karena antara huruf satu dengan huruf lainnya tidak berasal dari makhraj yang sama, tidak mengumpulkan 4 huruf berharakat dan juga adanya keselarasan harakat.

\section{Grafem / g / Dilambangkan dengan Grafem / أ/, / ז/, / / /}

Grafem /g/ di awal istilah dapat dilambangkan dengan grafem / ك/ / / / / / / ketika istilah tersebut dipinjam ke dalam bahasa Arab. Grafem/g/dengan posisi tersebut melambangkan fonem [g] seperti pada istilah gallon [gælən] maka dalam bahasa Arab ditulis dengan grafem / غ الغالون [al-gho:lu:n], sedangkan yang melambangkan fonem [d3] dalam bahasa Arab ditulis dengan grafem / ج/, seperti pada istilah gyroscope [d3arəskop] dengan الجيروسكوب [ald3i:rusku:b]. Jika grafem tersebut melambangkan fonem [g] kemudian suku kata berikutnya /va/ maka berubah dengan grafem / ك/, contohnya galvanism [galvanisəm] dengan الكَلْفانية [alkalfa:nijjah]. Sedangkan grafem $/ g /$ di tengah istilah bahasa Inggris berbunyi [d3], seperti dalam istilah giga 
hertz [d3igahertəz ] maka grafem /g/ berubah dengan grafem / $/$ / dan jika terletak di akhir istilah yang melambangkan bunyi [d3] seperti dalam istilah glass sponge [glæs spond3] maka /g/berubah dengan grafem/ r/. Secara ringkas dapat dilihat pada tabel berikut ini:

Tabel 4

Lambang Grafem /g/

\begin{tabular}{|c|c|c|c|c|c|c|c|}
\hline No & Distribusi & $\begin{array}{l}\text { Bahasa } \\
\text { Inggris }\end{array}$ & $\begin{array}{c}\text { Transkipsi } \\
\text { Fonetis } \\
\end{array}$ & $\begin{array}{c}\text { Bahasa } \\
\text { Arab }\end{array}$ & $\begin{array}{l}\text { Transkipsi } \\
\text { Ortografis }\end{array}$ & $\begin{array}{c}\text { Transkipsi } \\
\text { Fonetis } \\
\end{array}$ & $\begin{array}{c}\text { Perubahan } \\
\text { Grafem }\end{array}$ \\
\hline \multirow[t]{2}{*}{1.} & \multirow[t]{2}{*}{ awal } & gallon & [gælən] & ل الغالون & [al-gālūn] & [al-gho:lu:n] & $\mathrm{g} \rightarrow \dot{\xi}$ \\
\hline & & galvanism & [galvanisəm] & المَلْفانية & $\begin{array}{l}\text { [al- } \\
\text { kalfāniyyah] }\end{array}$ & $\begin{array}{l}\text { [alkalfa: } \\
\text { nijjah] }\end{array}$ & $g \rightarrow 5$ \\
\hline 2. & tengah & giga hertz & [d3igahsrtəz] & الجِيغاهيرتز & [al jīgāhirtiz] & $\begin{array}{l}\text { [ald3i:gha: } \\
\text { hirtəz] }\end{array}$ & $g \rightarrow \dot{\varepsilon}$ \\
\hline 3. & akhir & sponge & [spond3] & الإسْفَنْجَج & [al-isfanju] & [alisfand3] & $g \rightarrow T$ \\
\hline
\end{tabular}

Perubahan grafem /g/ menjadi / s/ tidak ditemukan dalam kaidah perubahan konsonan Majma' Lughah, begitu juga secara fonotaktik Arab, di mana huruf / r/ tidak disatukan dengan huruf / $/ \dot{\xi}$ dalam sebuah kata.

\section{Grafem /h/ Dilambangkan dengan Grafem / / / / / /}

Grafem /h/ di awal istilah dapat dilambangkan dengan grafem /。/ dan /ق/ ketika istilah tersebut dipinjam ke dalam bahasa
Arab. Grafem /h/ dengan posisi tersebut melambangkan fonem [h] dan setelahnya adalah grafem /a, e, o, y / dan terdiri dari dua suku kata atau lebih maka dalam bahasa Arab ditulis dengan grafem /\%/, seperti pada istilah halogen [hæləd3ən] dengan [alha:lu:d3i:n]. Sedangkan yang melambangkan fonem [h] dan setelahnya adalah grafem o [o] dan terdiri dari satu suku kata maka dalam bahasa Arab ditulis dengan grafem /ق/ق seperti pada istilah horn [horn] dengan قرن [qorn].

Tabel 5

Lambang Grafem / h /

\begin{tabular}{|c|c|c|c|c|c|c|c|}
\hline No & $\begin{array}{c}\text { Distri } \\
\text { busi }\end{array}$ & $\begin{array}{l}\text { Bahasa } \\
\text { Inggris }\end{array}$ & $\begin{array}{c}\text { Transkipsi } \\
\text { Fonetis }\end{array}$ & $\begin{array}{c}\text { Bahasa } \\
\text { Arab }\end{array}$ & $\begin{array}{l}\text { Transkipsi } \\
\text { Ortografis }\end{array}$ & $\begin{array}{c}\text { Transkipsi } \\
\text { Fonetis }\end{array}$ & $\begin{array}{c}\text { Perubahan } \\
\text { Grafem }\end{array}$ \\
\hline 1. & awal & halogen & [hæləd3ən] & الهالوجين & [al-hālūjīn] & [alha:lu:d3i:n] & $h \rightarrow$ 。 \\
\hline 2. & & & [hərn] & قرن & [qarn] & [qorn] & و \\
\hline
\end{tabular}

Istilah tersebut di atas sudah sesuai dengan kaidah fonotaktik bahasa Arab, karena antara huruf satu dengan huruf lainnya tidak berasal dari makhraj yang sama, tidak mengumpulkan 4 huruf berharakat. Sedangkan dari sisi kaidah konsonan Majma' Lughah tidak terdapat perubahan grafem / / / / /

\section{Grafem / p / Dilambangkan dengan Grafem /}

Grafem /p/ di awal istilah dapat dilambangkan dengan grafem / / ketika istilah tersebut dipinjam ke dalam bahasa Arab. Grafem /p/ dengan posisi tersebut melambangkan fonem [p], seperti pada istilah pantology [pəntəlJjI] dengan البَتْولوجيا [albantə:lu: d3iya:]. Jika jika grafem /p/ terletak di akhir istilah seperti gyroscope [d3ajrəskop] yang melambangkan fonem [p] maka grafem / p / berubah dengan grafem / ب/. 
Tabel 6

Lambang Grafem / p /

\begin{tabular}{|c|c|c|c|c|c|c|c|}
\hline No & $\begin{array}{c}\text { Distri } \\
\text { busi }\end{array}$ & $\begin{array}{l}\text { Bahasa } \\
\text { Inggris }\end{array}$ & $\begin{array}{c}\text { Transkipsi } \\
\text { Fonetis }\end{array}$ & $\begin{array}{c}\text { Bahasa } \\
\text { Arab }\end{array}$ & $\begin{array}{c}\text { Transkipsi } \\
\text { Ortografis }\end{array}$ & $\begin{array}{c}\text { Transkipsi } \\
\text { Fonetis }\end{array}$ & $\begin{array}{c}\text { Perubahan } \\
\text { Grafem }\end{array}$ \\
\hline 1. & aawal & pantology & [pəntələjI] & البَتُتولوجيا & [al-bantūlūjiyā] & $\begin{array}{l}\text { [albanto:lu: } \\
\text { d3iya:] }\end{array}$ & $p \rightarrow ب$ \\
\hline 2. & akhir & gyroscope & [d3ajrəskop] & الجيروسكوب & [al-jīrūskūb] & $\begin{array}{l}\text { [ald3i:rusku: } \\
\text { b] }\end{array}$ & $p \rightarrow ب$ \\
\hline
\end{tabular}

Istilah tersebut di atas sudah sesuai dengan kaidah fonotaktik bahasa Arab, karena antara huruf satu dengan huruf lainnya tidak berasal dari makhraj yang sama, tidak mengumpulkan 4 huruf berharakat.

\section{Grafem / s / Dilambangkan dengan Grafem w dan;}

Grafem /s/ di awal istilah dilambangkan dengan grafem /w/ dan / / ketika istilah tersebut diserap ke dalam bahasa Arab. Grafem /s/ dengan posisi tersebut yang melambangkan fonem [s] dan setelahnya adalah grafem /a/ [æ] , /c / [k] , /e/ [a], i $[\varepsilon], / o /[\supset], / t /[t], / u /[\supset], / y /[i] ~ m a k a$ dilambangkan dengan grafem /w/. Grafem /s/ di awal istilah dilambangkan dengan grafem / / / jika melambangkan fonem [s] dan setelahnya adalah grafem /o/ [o]seperti dalam istilah sodic [sodik] dengan صوديوميّ [〕っ:diju:m]. Grafem /s/di tengah istilah bahasa Inggris berbunyi [s], seperti dalam istilah stroboscope [strobosksp] maka grafem tersebut dilambangkan dengan grafem / $/$ /. Jika grafem tersebut melambangkan fonem [z] seperti dalam istilah seismometry [sajzmamətrI] maka dalam bahasa Arab dilambangkan dengan grafem / $/$ dan jika terletak di akhir istilah seperti dalam soubise [sobais] maka grafem /s/ berubah dengan grafem / $j /$.

Tabel 7

Lambang Grafem / s /

\begin{tabular}{|c|c|c|c|c|c|c|c|}
\hline No & $\begin{array}{c}\text { Distri } \\
\text { busi }\end{array}$ & $\begin{array}{l}\text { Bahasa } \\
\text { Inggris }\end{array}$ & $\begin{array}{c}\text { Transkipsi } \\
\text { Fonetis }\end{array}$ & $\begin{array}{c}\text { Bahasa } \\
\text { Arab }\end{array}$ & $\begin{array}{l}\text { Transkipsi } \\
\text { Ortografis }\end{array}$ & $\begin{array}{c}\text { Transkipsi } \\
\text { Fonetis }\end{array}$ & $\begin{array}{c}\text { Perubahan } \\
\text { Grafem }\end{array}$ \\
\hline \multirow[t]{2}{*}{1.} & \multirow[t]{2}{*}{ awal } & sodic & [sodik] & صوديوميّ & [șūdiyūm] & 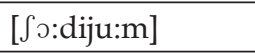 & $s \rightarrow \infty$ \\
\hline & & sodium & [sodiəm] & المُوديوم & [as-Ṣūdiyūm] & [as $\left.\int \supset: d i j u: m\right]$ & $s \rightarrow \infty$ \\
\hline 2. & tengah & stroboscope & [strobəskəp] & السّتروبوسكوب & [as-sitrūbūskūb] & [assitru:bosk॰:b] & s \\
\hline \multirow[t]{2}{*}{3.} & \multirow[t]{2}{*}{ akhir } & seismometry & [sajzmamətrl] & السَيزمومتريّة & [as-sizmūmitriyyah] & [assizmu:mətriyyah] & $s \rightarrow j$ \\
\hline & & soubise & [sobais] & السُبيز & [as-subīz] & [assubi:z] & $\mathrm{s} \rightarrow$; \\
\hline
\end{tabular}

Pada data tersebut di atas terdapat perbedaan dengan kaidah Majma' Lughah yaitu ketika fonem / s/ melambangkan fonem / z/ baik di tengah maupun di akhir dan juga tidak sejalan dengan fonotaktik bahasa Arab, namun dari sisi pola bunyi megikuti kaidah kesesuaian huruf dan keselarasan harakat.

\section{Grafem / t / Dilambangkan dengan Grafem / / dan / /}

Grafem / t / di awal istilah dapat dilambangkan dengan grafem / e/ dan / $\star /$ ketika istilah tersebut diserap ke dalam bahasa Arab. Grafem / t / dengan posisi tersebut melambangkan fonem [t] maka dalam bahasa Arab ditulis dengan grafem / ت/, seperti dalam istilah technetium [təknধtijom]. Grafem/t / di awal istilah yang melambangkan fonem $[\theta]$, dalam bahasa Arab ditulis dengan grafem / ث/ seperti dalam istilah thallic [Өælik] dengan ثاليومئ

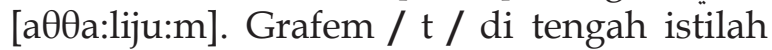
bahasa Inggris berbunyi [ $t$ ], seperti dalam istilah telephoto [teləfoto] berubah dengan grafem ت pada kata التِّفوتوغرافي [attalifutugro:fI] dan jika terletak di akhir istilah dan suku kata terakhir seperti dalam istilah teletext [telət\&kst] maka berubah dengan grafem / / dalam التَّلَيكست [attiliksi:t]. 
Tabel 8

Lambang Grafem / t /

\begin{tabular}{|c|c|c|c|c|c|c|c|}
\hline No & $\begin{array}{c}\text { Distri- } \\
\text { busi }\end{array}$ & $\begin{array}{l}\text { Bahasa } \\
\text { Inggris }\end{array}$ & $\begin{array}{l}\text { Transkipsi } \\
\text { Fonetis }\end{array}$ & $\begin{array}{c}\text { Bahasa } \\
\text { Arab }\end{array}$ & $\begin{array}{l}\text { Transkipsi } \\
\text { Ortografis }\end{array}$ & $\begin{array}{c}\text { Transkipsi } \\
\text { Fonetis }\end{array}$ & $\begin{array}{c}\text { Perubahan } \\
\text { Grafem }\end{array}$ \\
\hline 1. & awal & thallium & [Өæliəm] & الثًاليوم & [aś-śāliyūm] & 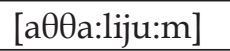 & \\
\hline 2. & tengah & technetium & [təkn\&tijom] & التَكنيتيوم & [at-taknītiyūm] & [attakni:tiju:m] & \\
\hline 3. & akhi r & teletext & [t\&latskst] & التَلَكست & [at-tiliksīt] & [at-tiliksìt] & $t \rightarrow ت$ \\
\hline
\end{tabular}

Ortografi istilah serapan di atas sudah sesuai dengan kaidah fonotaktik bahasa Arab karena antara huruf satu dengan huruf lainnya tidak berasal dari makhraj yang sama, terdapat keselarasan harakat dan kaidah konsonan yang dirumuskan oleh Majma' Lughah.

\section{Grafem / v / Dilambangkan dengan ا ف I, اب/ Grafem}

Grafem /v/ di awal istilah dapat dilambangkan dengan grafem / / ketika istilah tersebut diserap ke dalam bahasa Arab. Grafem/v/ di awal istilah dapat dilambangkan dengan grafem / ف/ jika melambangkan fonem [v] dan setelahnya adalah grafem /a/ [o], /i/ [ I], /o/ [o], /u/ [o] seperti pada istilah vanadinite [vənedinait] dengan الفانادينيت [alfa:na:di:ni:t]. Grafem / v / yang melambangkan fonem [v], setelahnya adalah grafem /o/ [a] dan terdiri lebih dari dua suku kata maka dalam bahasa Arab ditulis dengan grafem / ب/ seperti pada istilah volcanic [valkæn Ik] dengan بُركانيّ [burka:ni:]. Grafem /v/ di tengah istilah bahasa Inggris berbunyi [v], seperti dalam istilah galvanism [galvanisəm] maka berubah dengan grafem / الكَّفانية [alkalfa:ni:].

Tabel 9

Lambang Grafem / v /

\begin{tabular}{|c|c|c|c|c|c|c|c|}
\hline No & $\begin{array}{c}\text { Distri } \\
\text { busi }\end{array}$ & $\begin{array}{l}\text { Bahasa } \\
\text { Inggris }\end{array}$ & $\begin{array}{c}\text { Transkipsi } \\
\text { Fonetis }\end{array}$ & $\begin{array}{c}\text { Bahasa } \\
\text { Arab }\end{array}$ & $\begin{array}{l}\text { Transkipsi } \\
\text { Ortografis }\end{array}$ & $\begin{array}{c}\text { Transkipsi } \\
\text { Fonetis }\end{array}$ & $\begin{array}{c}\text { Perubahan } \\
\text { Grafem }\end{array}$ \\
\hline \multirow[t]{2}{*}{1.} & \multirow[t]{2}{*}{ awal } & vanadinite & [vənedinait] & الفانادينيت & [al-fānādīnīt] & [alfa:na:di:ni:t] & $f \rightarrow$ ف \\
\hline & & volcanic & [valkænIk] & لبُ بُركانيّ & [burkāniyy] & [burka:nI] & $\mathrm{f} \rightarrow \mathrm{u}$ \\
\hline 3. & tengah & galvanism & [galvanisəm] & الكَلْفانية & [al-kalfāniyyah] & [alkalfa:ni:] & $\mathrm{f} \rightarrow \mathrm{\omega}$ \\
\hline
\end{tabular}

Ortografi istilah serapan di atas sudah sesuai dengan kaidah fonotaktik bahasa Arab, karena antara huruf satu dengan huruf lainnya tidak berasal dari makhraj yang sama, adanya keselarasan harakat, tetapi tidak mengikuti kaidah perubahan konsonan Majma' Lughah.

\section{Grafem / x / Dilambangkan dengan كس dan}

Grafem $|x|$ di awal istilah dapat dilambangkan dengan grafem is ketika istilah tersebut diserap ke dalam bahasa Arab. Grafem $/ x /$ dengan posisi tersebut melambangkan fonem [z] dan setelahnya adalah grafem/a/ [ə], /y / [i:] maka dalam bahasa Arab ditulis dengan grafem/j/ seperti pada istilah xanthine [zəntin] dengan الزنتاين [azzantə:n]. Grafem /x/ di awal istilah yang melambangkan fonem [z], setelahnya adalah grafem / y/ [ai], suku kata berikutnya adalah / li/ [li]. Kata ini terdiri lebih dari dua suku kata maka dalam bahasa Arab ditulis dengan grafem / g/ seperti pada istilah xylitol [zailitol] dengan الويليتول [alwi:li:to:l]. Grafem $|x|$ di tengah dan di akhir istilah Inggris berbunyi [ks], seperti dalam istilah bauxite [boksajt] maka berubah dengan grafem كس seperti dalam istilah البوكسيت [albu:ksi:t], fax [fæks] dengan الفاكس [alfaks]. 
Tabel 10

Lambang Grafem / x /

\begin{tabular}{|c|c|c|c|c|c|c|c|}
\hline No & $\begin{array}{l}\text { Distri } \\
\text { busi }\end{array}$ & $\begin{array}{l}\text { Bahasa } \\
\text { Inggris }\end{array}$ & $\begin{array}{c}\text { Transkipsi } \\
\text { Fonetis }\end{array}$ & $\begin{array}{c}\text { Bahasa } \\
\text { Arab }\end{array}$ & $\begin{array}{l}\text { Transkipsi } \\
\text { Ortografis }\end{array}$ & $\begin{array}{c}\text { Transkipsi } \\
\text { Fonetis }\end{array}$ & $\begin{array}{c}\text { Perubahan } \\
\text { Grafem }\end{array}$ \\
\hline \multirow[t]{2}{*}{1.} & \multirow[t]{2}{*}{ awal } & xanthine & [zəntin] & الز الزنتاين & [az-zantāin] & [azzantə:n] & $x \rightarrow$; \\
\hline & & xylitol & [zailitol] & الويليتول & [al-wīlītūl] & [alwi:li:to:1] & $x \rightarrow g$ \\
\hline 2. & tengah & bauxite & [boksajt] & البوكسيت & [al-būksīt] & [albu:ksi:t] & x \\
\hline 3. & akhir & fax & [fæks] & الفاكس & [al-faks] & [alfaks] & $x \rightarrow$ كس \\
\hline
\end{tabular}

Ortografi istilah serapan di atas tampak perubahan yang terjadi tidak sesuai dengan kaidah Majma' Lughah, yakni grafem /x/ dilambangkan dengan grafem / $/ /, / j /$ ketika kata tersebut diserap ke dalam bahasa Arab.

\section{Grafem / z / Dilambangkan dengan Grafem / ;}

Grafem /z/ di awal dan tengah istilah dilambangkan dengan grafem / $/$ / ketika istilah tersebut diserap ke dalam bahasa Arab. Grafem / z / dengan posisi tersebut melambangkan fonem [z] seperti pada istilah zinc [zink] dengan الزنك [azzən], hydrazine [hajdrəzin] berubah dengan الهيدرازين [alhidru:zi:n]. Jika terletak di akhir suku kata yang melambangkan fonem [z] atau akhir kata yang melambangkan fonem [s] seperti dalam istilah hertz [herts] maka berubah dengan grafem / الهيرتز / yaitu pada kathi:rti:z].

Tabel 11

Lambang Grafem / z /

\begin{tabular}{|c|c|c|c|c|c|c|c|}
\hline No & $\begin{array}{l}\text { Distri } \\
\text { busi }\end{array}$ & $\begin{array}{l}\text { Bahasa } \\
\text { Inggris }\end{array}$ & $\begin{array}{c}\text { Transkipsi } \\
\text { Fonetis }\end{array}$ & $\begin{array}{c}\text { Bahasa } \\
\text { Arab }\end{array}$ & $\begin{array}{l}\text { Transkipsi } \\
\text { Ortografis }\end{array}$ & $\begin{array}{c}\text { Transkipsi } \\
\text { Fonetis }\end{array}$ & $\begin{array}{c}\text { Perubahan } \\
\text { Grafem }\end{array}$ \\
\hline 1. & awal & zinc & [zink] & ل & [az-zink] & [azzən] & $z \rightarrow j$ \\
\hline 2. & tengah & hydrazine & [hajdrəzin] & الهيدرازين & [al-hidrūzīn] & [alhidru:zi:n] & $\mathrm{z} \rightarrow$ \\
\hline 3. & akhir & hertz & [herts] & الهيرتز & [al-hirtīz] & [alhi:rti:z] & $\mathrm{z} \rightarrow$ \\
\hline
\end{tabular}

Grafem / $t$ yang Diikuti Morfem ion dan -ism Dilambangkan dengan Grafem :

Grafem $t$ yang diikuti morfem -ion dalam kata bahasa Inggris melambangkan bunyi [ $\left.\int ə n\right]$. Grafem ini untuk menunjukkan kata benda maka dalam bahasa Arab dilambangkan dengan grafem /。/, seperti dalam istilah serapan yang ditemukan dalam bahasa Arab pada tabel berikut ini:

Tabel 12

Grafem / t/ yang Diikuti Morfem -ion dan -ism Dilambangkan dengan Grafem a

\begin{tabular}{|c|c|c|c|c|c|}
\hline No & Bahasa Inggris & Fonem Bahasa Inggris & $\begin{array}{c}\text { Bahasa } \\
\text { Arab }\end{array}$ & $\begin{array}{c}\text { Fonem Bahasa } \\
\text { Arab }\end{array}$ & $\begin{array}{c}\text { Perubahan } \\
\text { Grafem }\end{array}$ \\
\hline 1 & carbonation & 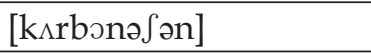 & الكَرَبنَة & [alkarbanah] & tion $\rightarrow$ : \\
\hline 2 & galvanism & [g $\Lambda \operatorname{lv} \wedge$ n I zəm] & الكَلْفانية & [alkalfa:nijah] & $-\mathrm{sm} \rightarrow:$ \\
\hline 3 & magnetism & [mægnət I zəm] & المَغْنِطيسيّة & [almaghniti:sijjah] & $-\mathrm{sm} \rightarrow 0$ \\
\hline
\end{tabular}

Grafem /s / dalam Grafem /-ics/ di Akhir Istilah Dilambangkan dengan

\section{Grafem / / dan}

Grafem s dalam grafem /-ics/ di akhir istilah Inggris yang menunjukkan nomina, baik kata benda atau pun suatu ilmu dan kajian, dilambangkan dengan grafem / I / dan / يّات / ketika diserap ke dalam bahasa Arab, seperti dalam istilah serapan yang ditemukan dalam bahasa Arab pada tabel berikut ini: 
Tabel 13

Grafem / s / dalam Grafem /-ics / di Akhir Istilah Dilambangkan dengan Grafem / 1 / dan

\begin{tabular}{|c|c|c|c|c|c|}
\hline No & Bahasa Inggris & $\begin{array}{c}\text { Fonem Bahasa } \\
\text { Inggris }\end{array}$ & Bahasa Arab & Fonem Bahasa Arab & $\begin{array}{c}\text { Perubahan } \\
\text { Grafem }\end{array}$ \\
\hline 1. & hydrodynamics & [hajdrodainamiks] & الهيدروديناميكا & [alhidro:di:na:mi:ka:] & $-\mathrm{ics} \rightarrow 1$ \\
\hline 2. & nucleonics & [nəklian I ks] & النُّوَوِيّات & [annuwawijja:t] & -ics \\
\hline
\end{tabular}

\section{Lambang Grafem yang Tidak Bersyarat}

Penggantian grafem tidak bersyarat yang dimaksud dalam artikel ini yaitu grafem baik yang menempati posisi di awal, tengah dan akhir istilah atau suku kata, maka grafem ini melambangkan fonem yang sama dalam bahasa Arab. Hasilnya secara umum lambang grafem yang ada, sesuai dengan kaidah yang dirumuskan Majma' Lughah dan fonotaktik bahasa Arab. Berikut merupakan uraian grafem-grafem yang tidak bersyarat.

Tabel 14

Lambang grafem / b/

\begin{tabular}{|c|c|c|c|c|c|c|c|}
\hline No & $\begin{array}{c}\text { Distri } \\
\text { busi }\end{array}$ & $\begin{array}{l}\text { Bahasa } \\
\text { Inggris }\end{array}$ & $\begin{array}{c}\text { Transkipsi } \\
\text { Fonetis }\end{array}$ & $\begin{array}{c}\text { Bahasa } \\
\text { Arab }\end{array}$ & $\begin{array}{l}\text { Transkipsi } \\
\text { Ortografis }\end{array}$ & $\begin{array}{c}\text { Transkipsi } \\
\text { Fonetis }\end{array}$ & $\begin{array}{c}\text { Perubahan } \\
\text { Grafem }\end{array}$ \\
\hline 1 & awal & barite & [b\&rajt] & الباريت & [al-bārīt] & [alba:ri:t] & $b \rightarrow u$ \\
\hline 2 & tengah & cable & [kebəl] & الكَبْل & [al-kabl] & [alkablu] & $b \rightarrow u$ \\
\hline
\end{tabular}

Grafem /d/ Dilambangkan dengan / s /

Grafem /d/ dalam bahasa Inggris hanya melambangkan satu bunyi, yaitu [d]. Dalam bahasa Arab bunyi [d] dilambangkan dengan grafem / د/. Grafem / d / dapat menempati

\section{Grafem /b/ Dilambangkan dengan /}

Grafem / b/ dalam bahasa Inggris hanya melambangkan satu bunyi, yaitu [b] maka dalam bahasa Arab bunyi [b] dilambangkan dengan grafem / ب/. Grafem /b/ dapat menempati posisi di awal suku kata seperti pada istilah barite [berajt] atau di tengah istilah Inggris seperti cable [kebəl], dan grafem /b/ dalam semua posisi ini melambangkan fonem $[b]$. posisi di awal suku kata seperti pada istilah decastere [dikastəir] atau di tengah istilah bahasa Inggris seperti videotext [v Idiotekst], dan grafem /d/ dalam semua posisi ini melambangkan fonem / d / .

Tabel 15

Lambang Grafem / d/

\begin{tabular}{|c|c|c|c|c|c|c|c|}
\hline No & $\begin{array}{c}\text { Distri- } \\
\text { busi }\end{array}$ & $\begin{array}{c}\text { Bahasa } \\
\text { Inggris }\end{array}$ & $\begin{array}{c}\text { Transkipsi } \\
\text { Fonetis }\end{array}$ & $\begin{array}{c}\text { Bahasa } \\
\text { Arab }\end{array}$ & $\begin{array}{l}\text { Transkipsi } \\
\text { Ortografis } \\
\end{array}$ & $\begin{array}{c}\text { Transkipsi } \\
\text { Fonetis } \\
\end{array}$ & $\begin{array}{c}\text { Perubahan } \\
\text { Grafem }\end{array}$ \\
\hline 1 & awal & $\begin{array}{l}\text { decameter also } \\
\text { decameter }\end{array}$ & [dikamitər] & الديكامتر & [ad-dīkāmitr] & [addi:ka:mitr] & $\mathrm{d} \rightarrow \mathrm{s}$ \\
\hline 2 & tengah & hydraulic & [hajdrol I k] & هيدروليكي" & [hidrūlīkiyy] & [hidru:li:kiy] & $\mathrm{d} \rightarrow \mathrm{s}$ \\
\hline
\end{tabular}

/ Grafem / f / Dilambangkan dengan /

Grafem / f / dalam bahasa Inggris hanya melambangkan satu bunyi, yaitu [f]. Dalam bahasa Arab bunyi [f] dilambangkan dengan grafem / ف /. Grafem / f / dapat menempati posisi di awal suku kata seperti pada istilah fax [fæks] atau di tengah istilah Inggris seperti paraffin [perəfən], dan grafem / f / dalam semua posisi ini melambangkan fonem $[\mathrm{f}]$.

Tabel 16

Lambang Grafem /f/

\begin{tabular}{l|l|l|l|l|l|l|l}
\hline No & $\begin{array}{c}\text { Distri- } \\
\text { busi }\end{array}$ & $\begin{array}{c}\text { Bahasa } \\
\text { Inggris }\end{array}$ & $\begin{array}{c}\text { Transkipsi } \\
\text { Fonetis }\end{array}$ & $\begin{array}{c}\text { Bahasa } \\
\text { Arab }\end{array}$ & $\begin{array}{c}\text { Transkipsi } \\
\text { Ortografis }\end{array}$ & $\begin{array}{c}\text { Transkipsi } \\
\text { Fonetis }\end{array}$ & $\begin{array}{c}\text { Perubahan } \\
\text { Grafem }\end{array}$ \\
\hline 1. & awal & fax & {$[$ fæks] } & الفاكس & [faks] & [fəks] & $\mathrm{f} \rightarrow \omega$ \\
\hline 2. & tengah & paraffin & [p\&rəfən] & [al-bārāfīn] & [alba:ra:fi:n] & $\mathrm{f} \rightarrow \omega$ \\
\hline
\end{tabular}


Grafem / k / Dilambangkan dengan / s/

Grafem / k/ dalam bahasa Inggris hanya melambangkan satu bunyi, yaitu [k]. Dalam bahasa Arab bunyi [k] dilambangkan dengan grafem /s/. Grafem /k/ dapat menempati posisi di awal suku kata seperti pada istilah kilobar [ $\mathrm{k} \mathrm{l} l a b \wedge \mathrm{r}]$ atau di tengah seperti leukemia [lukimia], dan grafem / k / dalam semua posisi ini melambangkan fonem $/ \mathrm{k} /$.

Tabel 17

Lambang Grafem / k/

\begin{tabular}{|c|c|c|c|c|c|c|c|}
\hline No & $\begin{array}{c}\text { Distri } \\
\text { busi }\end{array}$ & $\begin{array}{l}\text { Bahasa } \\
\text { Inggris }\end{array}$ & $\begin{array}{l}\text { Transkipsi } \\
\text { Fonetis }\end{array}$ & $\begin{array}{c}\text { Bahasa } \\
\text { Arab }\end{array}$ & $\begin{array}{l}\text { Transkipsi } \\
\text { Ortografis }\end{array}$ & $\begin{array}{c}\text { Transkipsi } \\
\text { Fonetis }\end{array}$ & $\begin{array}{c}\text { Perubahan } \\
\text { Grafem }\end{array}$ \\
\hline 1 & awal & kilobar & {$\left[\mathrm{k}_{\mathrm{I}} \mathrm{l} \partial \mathrm{b} \wedge \mathrm{r}\right]$} & ل & [al-kīlūbār] & [alki:lっ:ba:r] & $k \rightarrow s$ \\
\hline 2 & tengah & leukemia & [lukimiə] & اللّوكيميا & [al-lūkīmiyā] & [allu:ki:mija:] & $\mathrm{k} \rightarrow \mathrm{s}$ \\
\hline
\end{tabular}

Grafem / / Dilambangkan dengan / J /

Grafem / 1 / dalam bahasa Inggris hanya melambangkan satu bunyi, yaitu [1]. Dalam bahasa Arab bunyi [1] dilambangkan dengan grafem / J /. Grafem / 1 / dapat menempati posisi di awal suku kata seperti pada istilah limonite [lajmənajt], ditengah seperti astrolabe [æz tro leb] dan di akhir istilah Inggris seperti cholesterol [kəlestərol], dan grafem /1/ dalam semua posisi ini melambangkan fonem / $1 /$.

Tabel 18

Lambang Grafem /1/

\begin{tabular}{|c|c|c|c|c|c|c|c|}
\hline No & $\begin{array}{c}\text { Distri } \\
\text { busi }\end{array}$ & $\begin{array}{l}\text { Bahasa } \\
\text { Inggris }\end{array}$ & $\begin{array}{l}\text { Transkipsi } \\
\text { Fonetis }\end{array}$ & $\begin{array}{c}\text { Bahasa } \\
\text { Arab }\end{array}$ & $\begin{array}{l}\text { Transkipsi } \\
\text { Ortografis }\end{array}$ & $\begin{array}{c}\text { Transkipsi } \\
\text { Fonetis }\end{array}$ & $\begin{array}{c}\text { Perubahan } \\
\text { Grafem }\end{array}$ \\
\hline 1. & awal & langley & [læyli] & اللأنغلي & [al-langaliy] & [allanghali:] & $1 \rightarrow J$ \\
\hline 2. & tengah & astrolabe & [æz troleb] & الأسمُطْلاب & [al-us țurlāb] & [al?usțurla:b] & $1 \rightarrow J$ \\
\hline 3. & akhir & cholesterol & [kəlestərol] & الكلولسترول & [al-kūlustirūl] & [alkulus:listiru:1] & $1 \rightarrow J$ \\
\hline
\end{tabular}

Grafem / m / Dilambangkan dengan /

Grafem / $\mathrm{m} /$ dalam bahasa Inggris hanya melambangkan satu bunyi, yaitu [m]. Dalam bahasa Arab bunyi $[\mathrm{m}]$ dilambangkan dengan grafem $/ \mathrm{p} /$. Grafem $/ \mathrm{m} /$ dapat menempati posisi di awal suku kata seperti pada istilah machinist [mI $\int$ inəst], di tengah seperti isomer [ajsəmər] atau di akhir istilah Inggris seperti uranium [jəreniəm], dan grafem $/ \mathrm{m} /$ dalam semua posisi ini melambangkan fonem $/ \mathrm{m} /$.

Tabel 19

Lambang grafem / m/

\begin{tabular}{|c|c|c|c|c|c|c|c|}
\hline No & $\begin{array}{l}\text { Distri } \\
\text { busi }\end{array}$ & $\begin{array}{l}\text { Bahasa } \\
\text { Inggris }\end{array}$ & $\begin{array}{c}\text { Transkipsi } \\
\text { Fonetis }\end{array}$ & $\begin{array}{c}\text { Bahasa } \\
\text { Arab }\end{array}$ & $\begin{array}{l}\text { Transkipsi } \\
\text { Ortografis }\end{array}$ & $\begin{array}{c}\text { Transkipsi } \\
\text { Fonetis }\end{array}$ & $\begin{array}{c}\text { Perubahan } \\
\text { Grafem }\end{array}$ \\
\hline 1. & awal & machinist & {$\left[\mathrm{m}_{\mathrm{I}} \int \mathrm{in} \partial \mathrm{st}\right]$} & الميكانيكي" & [al-mīkānīkīy] & [almi:ka:nikI] & $\mathrm{m} \rightarrow$ \\
\hline 2. & tengah & isomer & [ajsəmər] & الأيسومر & [al-aisūmir] & [al?aisumar] & $m \rightarrow \rho$ \\
\hline 3. & akhir & uranium & [jəreniəm] & اليورانيوم & [al-yūrāniyūm] & [alju:ra:niju:m] & $\mathrm{m} \rightarrow ?$ \\
\hline
\end{tabular}

Grafem / n / Dilambangkan dengan /

Grafem /n/ dalam bahasa Inggris hanya melambangkan satu bunyi, yaitu [n] maka dalam bahasa Arab bunyi [n] dilambangkan dengan grafem /ن/. Grafem /ن/ dapat

Tabel 20

Lambang Grafem /n/

\begin{tabular}{|c|c|c|c|c|c|c|c|}
\hline \multicolumn{8}{|c|}{$\begin{array}{c}\text { Tabel } 20 \\
\text { Lambang Grafem /n/ }\end{array}$} \\
\hline No & $\begin{array}{l}\text { Distri } \\
\text { busi }\end{array}$ & $\begin{array}{l}\text { Bahasa } \\
\text { Inggris }\end{array}$ & $\begin{array}{l}\text { Transkipsi } \\
\text { Fonetis }\end{array}$ & $\begin{array}{c}\text { Bahasa } \\
\text { Arab }\end{array}$ & $\begin{array}{c}\text { Transkipsi } \\
\text { Ortografis }\end{array}$ & $\begin{array}{l}\text { Transkipsi } \\
\text { Fonetis }\end{array}$ & $\begin{array}{l}\text { Perubahan } \\
\text { Grafem }\end{array}$ \\
\hline 1. & awal & neutron & [nutran] & النّيوترون & [an-niyutr ūn] & [annijo: tro:n] & $n \rightarrow$ i \\
\hline 2. & tengah & $\begin{array}{l}\text { oceano- } \\
\text { grapher }\end{array}$ & $\begin{array}{l}\text { [o } \text { \ənagrəfər } \\
\text { om mitər] }\end{array}$ & الأوقيانوغرافيّ & $\begin{array}{l}\text { [al- } \\
\text { uqiyānugrāfiy] }\end{array}$ & $\begin{array}{l}\text { [al?uqija: } \\
\text { nurra:fiy] }\end{array}$ & $n \rightarrow ن$ \\
\hline
\end{tabular}

menempati posisi di awal suku kata seperti pada istilah neutron [nutran] atau di tengah seperti oceanographer dan di akhir istilah Inggris seperti electron [olsktran] dan grafem / n / dalam semua posisi ini melambangkan fonem [n]. 


\begin{tabular}{l|c|c|c|c|c|c|c}
\hline No & $\begin{array}{c}\text { Distri } \\
\text { busi }\end{array}$ & $\begin{array}{c}\text { Bahasa } \\
\text { Inggris }\end{array}$ & $\begin{array}{c}\text { Transkipsi } \\
\text { Fonetis }\end{array}$ & $\begin{array}{c}\text { Bahasa } \\
\text { Arab }\end{array}$ & $\begin{array}{c}\text { Transkipsi } \\
\text { Ortografis }\end{array}$ & $\begin{array}{c}\text { Transkipsi } \\
\text { Fonetis }\end{array}$ & $\begin{array}{c}\text { Perubahan } \\
\text { Grafem }\end{array}$ \\
\hline 3. & akhir & electron & [əlektran] & [al-aliktirūn] & [alialiktru:n] & $\mathrm{n} \rightarrow \dot{\mathrm{l}}$ \\
\hline
\end{tabular}

Grafem /r / Dilambangkan dengan / , /

Grafem / r/ dalam bahasa Inggris hanya melambangkan satu bunyi, yaitu [r]. Dalam bahasa Arab bunyi [r] dilambangkan dengan grafem / J/. Grafem /r/ dapat menempati posisi di awal seperti pada istilah radiological [rediəlad3ıkəl], di tengah barometer [bəramətər] atau di akhir istilah Inggris scooter [skutər], dan grafem /r/ dalam semua posisi ini melambangkan fonem $[\mathrm{r}]$.

Tabel 21

Lambang Grafem / r/

\begin{tabular}{|c|c|c|c|c|c|c|c|}
\hline No & $\begin{array}{c}\text { Distri } \\
\text { busi }\end{array}$ & $\begin{array}{c}\text { Bahasa } \\
\text { Inggris }\end{array}$ & $\begin{array}{c}\text { Transkipsi } \\
\text { Fonetis }\end{array}$ & $\begin{array}{c}\text { Bahasa } \\
\text { Arab }\end{array}$ & $\begin{array}{l}\text { Transkipsi } \\
\text { Ortografis }\end{array}$ & $\begin{array}{c}\text { Transkipsi } \\
\text { Fonetis }\end{array}$ & $\begin{array}{c}\text { Perubahan } \\
\text { Grafem }\end{array}$ \\
\hline 1. & awal & radiological & [rediəlad3ıkəl] & راديولوجيّ & [rādiyūlū jiy] & [ra:diyə:lu:d3I] & $\mathrm{r} \rightarrow$ \\
\hline 2. & tengah & barometer & bəramətər] & البارومتر & [al-bārūmitr] & [alba:ru:mitr] & $\mathrm{r} \rightarrow$ \\
\hline 3. & akhir & scooter & [skutər] & السَّكْتورة & [as-saktūrah] & [assaktu:ra] & $\mathrm{r} \rightarrow$ \\
\hline
\end{tabular}

\section{Penghilangan Grafem yang Bersyarat}

Bentuk ortografi istilah serapan bahasa Inggris dalam bahasa Arab yang lainnya dilakukan dengan menghilangkan grafem istilah Inggris yang tidak melambangkan fonem. Pada bahasa Inggris tidak setiap grafem dalam suatu kata melambangkan satu fonem. Ada satu atau lebih garfem dalam istilah Inggris yang tidak melambangkan suatu fonem. Sebaliknya, setiap grafem atau bahkan dua grafem dalam bahasa Arab melambangkan satu fonem. Oleh karena itu, grafem yang tidak melambangkan fonem dalam suatu kata serapan dihilangkan ketika disesuaikan ke dalam bahasa Arab. Secara rinci penghilangan grafem dalam istilah Inggris yang muncul dalam bahasa Arab disajikan pada bagian-bagian berikut ini:

\section{Penghilangan Salah Satu Grafem Konsonan Ganda}

Istilah serapan dari bahasa Inggris banyak yang mengandung deret konsonan ganda. Ketika istilah tersebut masuk ke dalam bahasa Arab, salah satu dari konsonan dalam deret konsonan dihilangkan dikarenakan tidak melambangkan fonem. Istilah dan kata bahasa Inggris dengan deret konsonan ganda yang dihilangkan salah satunya yang ditemukan pada bahasa Arab disajikan dalam tabel berikut ini:

Tabel 22

Penghilangan Salah Satu Grafem Konsonan Ganda

\begin{tabular}{|c|c|c|c|c|c|}
\hline No & $\begin{array}{l}\text { Bahasa } \\
\text { Inggris }\end{array}$ & Fonem Bahasa Inggris & $\begin{array}{c}\text { Bahasa } \\
\text { Arab }\end{array}$ & Fonem Bahasa Arab & $\begin{array}{c}\text { Perubahan } \\
\text { Grafem }\end{array}$ \\
\hline 1. & potassium & [pətæsiəm] & البوتاسيوم & [albu:ta:siju:m] & SS $\rightarrow$ س \\
\hline 2. & megawatt & [megəwat] & ميجاوات & [mija:wa:t] & $\mathrm{tt} \rightarrow \mathrm{H}$ \\
\hline 3. & nitroparaffin & [nətrop\&rəfein] & الثّّروبارافين & [annitro:ba:ra:fi:n] & ف \\
\hline
\end{tabular}

Tabel di atas menunjukkan bahwa grafem ganda /ss/, /tt/ /ff/ dalam istilah Inggris dengan grafem tunggal: /, / / / / / ف/ / ketika diserap ke dalam bahasa Arab. Ini berarti salah satu dari masing-masing grafem ganda tersebut ditanggalkan. Grafem /s/ dan / $\mathrm{t} /$ ganda bisa terletak di tengah atau di akhir istilah, sedangkan grafem-grafem ganda lainnya terletak di tengah kata. Semua grafem ganda tersebut melambangkan fonem-fonem konsonan. Data ini juga selaras dengan fonotaktik dan kaidah perubahan konsonan dari Majma' Lughah.

\section{Lambang Dua Buah Grafem Konsonan Ganda}

Grafem ganda tidak hanya disesuaikan dengan satu grafem dalam bahasa Arab, tapi ada pula yang ditulis dengan dua grafem, sebagaimana dalam tabel di bawah ini: 
Tabel 23

Lambang Dua Buah Grafem Konsonan Ganda

\begin{tabular}{|c|c|c|c|c|c|}
\hline No & Bahasa Inggris & $\begin{array}{c}\text { Fonem Bahasa } \\
\text { Inggris }\end{array}$ & $\begin{array}{c}\text { Bahasa } \\
\text { Arab }\end{array}$ & Fonem Bahasa Arab & $\begin{array}{c}\text { Perubahan } \\
\text { Grafem }\end{array}$ \\
\hline 1. & saccharin & [sækərən] & ل & [assukkari:n] & 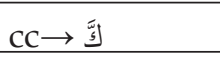 \\
\hline 2. & scooter & [skutər] & السَّكْتورة & [assaktu:roh] & OO $\rightarrow$ ت \\
\hline 3. & tellurite & [telorit] & التَّلَّريت & [attolu:ri:t] & $11 \rightarrow \breve{J}$ \\
\hline
\end{tabular}

Tabel di atas menunjukkan bahwa grafem ganda /c/ dan /1 /dalam istilah Inggris dilambangkan dengan /孚/ dan / J/ ketika istilah yang mengandung grafem ganda tersebut diserap ke dalam bahasa Arab. Grafem /c/ dan /l/ ganda bisa terletak di tengah istilah, sedangkan grafem ganda / o/ dengan / ت/ terletak di tengah istilah juga. Grafem ganda /c/ dan /1/ melambangkan fonem konsonan sedangkan grafem ganda /o/ melambangkan fonem vokal.

\section{Lambang Fonem yang Bersyarat dan Grafemnya}

Secara fonotaktik, kata-kata di dalam bahasa Arab pada dasarnya berakhir dengan konsonan. Untuk mengindari deret konsonan lebih dari satu di akhir, konsonan /t/ dan /d/ yang diawali konsonan di akhir suku kata atau di akhir istilah Inggris yang masuk ke dalam bahasa Arab dihilangkan. Fonem-fonem tersebut sebenarnya juga kurang begitu terdengar dan cenderung

tidak diucapkan oleh penutur bahasa Arab ketika mengucapkan istilah Inggris yang mengandung fonem-fonem tersebut. Selain fonem-fonem tresebut, fonem /i/ di akhir istilah tertentu juga dihilangkan. istilah Inggris dengan fonem-fonem tersebut yang muncul dalam bahasa Arab disajikan dalam pembahasan berikut;

\section{Lambang Fonem di Akhir Istilah}

Dalam bahasa Arab pada artikel ini ditemukan istilah yang berubah bentuknya karena fonem akhir disesuaikan dengan bentuk di dalam bahasa Arab,, seperti istilah vietnamese yang berfonem [vistnamis] dalam bahasa Inggris, grafemnya di dalam bahasa Arab menjadi الفيتنايّ [alfi:tna:miy]. Istilah vietnamese ditulis dengan الفيتنايّي dalam bahasa Arab menunjukkan fonem [s] pada istilah Inggris tersebut mengalami penyesuaian dikarenakan fonem tersebut menunjukkan ajektiva di dalam bahasa Arab sehingga digantikan dengan grafem / $/$.

Tabel 24

Lambang Fonem di Akhir Kata

\begin{tabular}{|c|c|c|c|c|}
\hline No & Bahasa Inggris & Fonem Bahasa Inggris & Bahasa Arab & Fonem Bahasa Arab \\
\hline 1. & vietnamese & [vistnamis] & الفيتناميّ & [alfi:tna:miy] \\
\hline 2. & ionic & [ajan Ik] & أيونيّ & [ayu:nI] \\
\hline 3. & machinist & [mi I inəst] & الميكانيكي & [almi:ka:ni:kiy] \\
\hline 4. & radiologist & [redialəd3əst] & الراديولوجيّ & [arra:diju:lud3iy] \\
\hline
\end{tabular}

\section{SIMPULAN}

Disimpulkan bahwa istilah serapan dari bahasa Inggris dilambangkan ke dalam bahasa Arab terdiri dari lambang grafem yang bersyarat dan lambang grafem yang tidak bersyarat. Istilah serapan dari bahasa Inggris, ada yang dilambangkan tidak sesuai dengan fonotaktik bahasa Arab yang disebabkan oleh beberapa hal sebagai berikut: pertama adanya satu grafem dari istilah serapan yang disesuaikan dengan banyak grafem; kedua, adanya satu grafem dari istilah serapan yang dapat melambangkan banyak fonem seperti grafem /s/ dengan grafem $\omega, \omega$, dan j; ketiga, adanya istilah serapan memiliki fonotaktik yang tidak terdapat dalam bahasa Arab sebelumnya, seperti istilah yang memiliki gugus konsonan

Temuan lainnya, yaitu terdapat tambahan kaidah lambang grafem konsonan dari 
Majma' Lughah Kairo yang terakhir ditetapkan pada Kongres ke-30 tahun 1963. Contohnya yaitu jika dalam kaidah Majma' Cairo: huruf / x/ dapat dilambangkan dengan maka ditambahkan dalam artikel ini dapat dilambangkan dengan grafem $\mathrm{g}$.

\section{DAFTAR PUSTAKA}

Ba'albaky, Munir. 2009. Al-Mawrid: A Modern English Arabic Dictionary. Edisi Pertama Dārul-'Ilmilil-Malayin. Beirut.

Chejne, Anwar G. t.t.. Bahasa Arab dan Peranannya dalam Sejarah (The Arabic Language: its Role in History). Terjemahan Aliudin Mahjudin. tt. Edisi Pertama Pusat Pembinaan dan Pengembangan Bahasa. Jakarta.

Crowley, Terry. 1992. An Introduction to Historical Linguistic. $1^{\text {st }}$ ed. Oxford University Press. New York.

Digital Program Version 1.1 Al-Wusțo Digital Publishing. 2010.

Hadi, Syamsul. 2005. Glosarium Kata dan Istilah Asing dalam Bahasa Arab. Edisi Pertama. Penerbitan Sastra Asia Barat FIB UGM. Yogyakarta.

Haugen, Einar. 1992. "Borrowing An Overview" Dalam William Bright.
International Encyclopedia of Linguistics. First ed. Oxford University Press. Oxford

Kesuma, Tri Mastoyo Jati. 2007. Pengantar (Metode) Penelitian Bahasa. Yogyakarta: Carasvatilbooks.

Khasārah, Mamduh Muhammad. 2008.'Ilmu al-Musthalah wa Thara'iq Wad'i alMusthalahāt fi al-'Arabiyah. Edisi Pertama. Darul Fikr. Damaskus.

Kridalaksana, Harimurti. 2008. Kamus Lingustik. Jakarta: Gramedia

Markaz Atlas al-'ālamī liddirāsāt wal abhās. 2005. Atlas Encyclopedic Dictionary English-Arabic. Edisi Ketiga. AsSyirkah ad-Dauliyyah Littibā'ah. Madinah

Murād, Ibrāhīm bin. 1997. Muqaddimah li Nazariyyah al-Mu'jam. Edisi Pertama Dār al-Garb al-Islāmiy. Beirūt.

Qanibiy, Hamid Shadiq, 2000. Al-Mā'jim wal Mushthalahāt Mabāhits fi alMushthalahāt wal Ma'äjimwat Ta'rīb. Arab Saudi:Dār Sa'ūdiyyah.

Sloat, Clarence, 1978. Introduction to Phonology. Prentice Hall: Englewood Cliffs, N.J.

Sudaryanto. 1986. Metode Linguistik: Ke Arah Memahami Metode Linguistik. Yogyakarta: GMU Press. 